\title{
The right to infrastructure: a struggle for sanitation in Fresno, California homeless encampments
}

Jessie Speer, Department of Geography, Syracuse University

\begin{abstract}
In 2013, Fresno, California was home to more than 5,000 homeless people, many of whom took refuge in sprawling downtown encampments. Citing unsanitary conditions, Fresno officials implemented a policy of bulldozing the encampments while providing housing vouchers to a small number of residents. Yet homeless Fresnans by and large demanded the provision of sanitation in the encampments as an alternative to eviction. In doing so, they invoked their right to urban infrastructure. Drawing from literature on informal housing in the Global South, this paper argues that individual housing rights present a limited framework through which to understand homeless people's right to the city, and that a truly radical right to the city should reflect the demand for sanitation infrastructure emerging from the streets.
\end{abstract}

\section{Introduction}

I followed the railroad tracks just west of the highway. On the other side of the overpass, a row of shanties leaned against a fenced-in warehouse. Up ahead an irrigation canal cut through the dirt as it made its way into the fields. Peaches ${ }^{1}$ protected her yard with an outer wall made of branches stacked several feet high. In front, there was a wooden gate and a bell for guests to ring. Her house was 100 square feet inside and elevated off the ground to keep out rats and insects. She had a mattress, two chairs, a dresser with drawers, a closet with clothes on hangers, and an ornate set of candle holders mounted on the wall. Her ceiling was constructed of ropes and tarps. She described it as a "living sculpture" that she tightened and retied like the sails of a ship. At the camp, she had a portable toilet and water for bathing and drinking. The canal used to be clogged with shopping carts and trash but she cleared it all out. After a chatting for a few hours, we headed down to the swift, cool waters.

\footnotetext{
${ }^{1}$ Homeless research participants are identified by pseudonyms to protect their identity.
} 


\section{Introduction}

As of last year, at least 100 homeless encampments existed in cities across the United States (Hunter, Linden-Retek, Shebaya, \& Halpert, 2014). Such "tent cities" provide much-needed shelter on the streets but are plagued by an extreme lack of sanitation infrastructure (Loftus-Farren, 2011). Despite this, US homelessness policy treats people living in informal housing as "unsheltered" and privileges individual housing rights over collective rights to urban infrastructure. Drawing on literature on informal housing in the Global South, this paper documents how the immediate struggles of those living in encampments in Fresno, California center more on access to sanitation than they do on housing. I elaborate on this finding to argue that a truly radical right to the city should reflect the demand for sanitation infrastructure emerging from the street, and infrastructural rights enable more collective and globally relevant forms of urban struggle. While this argument remains grounded in the historical and geographical specificity of Fresno, it has potential implications for theorizing urban homelessness and resistance more broadly.

This article is based on 2 months of ethnographic and archival research in Fresno, as well as 24 interviews with homeless people, activists, and officials. The canal bank encampment described above was one of more than seven camps I visited in in 2013. Over the last decade, Fresno, California has been home to multiple large-scale homeless encampments with limited access to basic infrastructural services. Yet local officials ignored the need for sanitation infrastructure in the encampments and instead implemented two contradictory policies toward homelessness: the Housing Authority provided housing vouchers to a small subset of Fresno's homeless community, while the city waged an eviction campaign to bulldoze informal homes in the encampments. Lack of infrastructural access often provided the pretext for evictions, as the city cited sanitation concerns to justify bulldozing people's tents and shanties. Despite this, local homeless people and advocates waged a tireless campaign to demand sanitation infrastructure in the encampments.

In the following section, I draw from literature on informal housing in the Global South to shed light on the connections between sanitation infrastructure and urban exclusion in US encampments. I then examine the relationship between sanitation and encampment evictions in Fresno and document the struggle for sanitation infrastructure that emerged from Fresno homeless encampments. Finally, I conclude by reflecting on how the situation in Fresno provokes new directions in the conversation about housing, infrastructure, and the right to the city, and serves as a reminder that radical urban struggles must be distinguished from individual rights. 


\section{Infrastructure and exclusion}

A growing body of scholarship has shown how lack of infrastructural access contributes to urban exclusion in the Global South. Sanitation in particular emerges as a central concern for the informally housed across much of the world. Roy (2003) and Sparks (2015) argue that it is crucial to bring theoretical insights from the Global South to bear on empirical situations in the United States in an effort to create broader transnational theory in the context of homelessness and informal housing. Responding to their call, in this section I turn to literature on infrastructure and informal housing in the Global South to shed greater light on sanitation struggles in the United States.

Scholars often characterize urban infrastructure as a defining feature of modern life (Edwards, 2004; Graham \& Marvin, 2001). Larkin (2013, p. 337) argues that infrastructure creates a sense of modernity - "a process by which the body, as much as the mind, apprehends what it is to be modern, mutable, and progressive." Infrastructure is often assumed to be a system in the background of modern life, only noticeable when it fails (Edwards, 2004; Star, 1999). Particularly since the mid-twentieth century, infrastructural networks have become part of the taken-for-granted world of everyday urban life (Greenberg \& Garver, 1998). Yet under capitalism, infrastructures often operate for profit and many cannot access the benefits they provide. This is particularly marked in the case of global access to sanitation infrastructure, as "the numbers of people without adequate access to safe drinking water or effective sanitation have grown inexorably over the last quarter century" (Gandy, 2005, p. 42).

Much of the literature on sanitation infrastructure emerges from the Global South. In 2003, less than one third of people living in cities in Africa, Asia and Latin America had access to what the United Nations calls "good quality sanitation" and as many as 100 million people were forced to defecate in the open because they did not have access to toilets (UN Habitat, 2003, p. xvii). Pindell (2006) notes that in Brazilian favelas, even after legislation significantly expanded the right of people to own homes in illegal settlements, many still struggled from a lack of infrastructural services. Thus, even as cities make progress on the right to housing, infrastructural access lags far behind.

Infrastructural inequality and exclusion is often culturally marginalizing (Gandy, 2005; McFarlane \& Rutherford, 2008). As Edwards (2004, pp. 189190) writes, "belonging to a culture means, in part, having fluency in its infrastructures ... in this sense, infrastructures constitute society." Infrastructures commit society to a pre-made system of order, control and regularity. Gandy $(2005$, p. 25) calls these networks a concrete manifestation of "normative universalism." Thus, being excluded from infrastructural 
access can lead to exclusion from societal norms. This normativity of infrastructural access is particularly marked with regards to the management of urban waste. Historically, colonial sanitation infrastructure was often linked to racialized discourses of disgust at the colonial "other" (McFarlane \& Rutherford, 2008; Michelle \& Bakker, 2008). Discourses about "promiscuous defecation" encouraged a "massive, ceaseless disinfection" of colonial cities, demanding control and quarantine (Anderson, 1995, p. 641). Similarly, in European cities, as private indoor bathrooms became the nineteenth century bourgeoisie norm, "the smell of human excrement ... was to be indicative of disorder, decay and physical repulsion" (Gandy, 1999, p. 32). This repulsion became associated with those who could not afford access to sanitation infrastructure.

Colonial categories of hygiene persist today. Chatterjee (2004) notes the ways in which people living in informal housing in India are treated as second-class citizens. McFarlane (2008, p. 91) argues that people in informal settlements in Mumbai are often depicted as "problem" rather than "citizen." He writes:

The view peddled in the media and among many neighbourhood improvement groups is often that it is their fault that sanitation is the way it is, and if things don't improve then it is they who are to blame ... "Slums" remain populations outside of the sphere of citizenship, outside of discourses of rights, and remain in the view of these officials and many others in the city a necessary scourge on visions of the modern, clean and ordered city. (2008, pp. 105-106)

These discourses often contribute to policies of spatial control and exclusion. Gandy (1999) writes that people without access to sanitation in nineteenth century European cities were increasingly pushed into marginalized city spaces. In modern-day Mumbai, public health discourses are associated with the increasing occurrence of slum demolition. As Chatterjee (2004, p. 140) writes, "many middleclass neighbourhood organisations in Mumbai ... interpret the sanitising of urban space through a logic of demolition rather than one of improvement of informal settlements. They often campaign to rid the city of encroachers and polluters and, as it were, to give the city back to its proper citizens." In the winter of 2005, an estimated 90,000 huts were torn down in Mumbai, leaving around 350,000 people homeless (McFarlane, 2008, p. 92). Similarly, Operation Drive Out Rubbish in Zimbabwe left as many as one million people homeless. The government argued that in destroying people's homes, it was simply clearing out "rubbish" to make way for more sanitary urban spaces (Institute for War and Peace Reporting, 2005).

Yet lack of infrastructural access does not only affect people living in the Global South. For homeless people living in the United States, inadequate 
infrastructure also results in exclusion and marginalization. The fact that homeless people cannot access sanitation infrastructure leads to a stigmatizing rhetoric of homeless people as "crazies" who choose to openly defecate in public. Burnes and Baum famously argued that the homeless are not simply poor, because poor people "do not urinate or defecate in public places" (as quoted in Mitchell, 2003, pp. 202-203). De Venanzi (2008) explains stigma against the homeless by arguing that society views poor hygiene as a rejection of convention. Yet this view ignores the unequal access to infrastructure that often prevents compliance with sanitary norms.

The notion that homeless people defecate in public is often used to support their removal from public space. Throughout the 1980s in America, a growing trend of urban revitalization coincided with the passage of antihomeless laws and a greater policing of the homeless (Mitchell, 1997). As post-industrial cities sought to redevelop downtown spaces, they targeted the homeless for "offending the senses" of upwardly mobile consumers (Mair, 1986, p. 359). Ed Koch, onetime mayor of New York City, said in support of an anti-loitering law: "These homeless people, you can tell who they are. They're sitting on the floor, occasionally defecating, urinating" (Dunlap, 1988). In San Diego, a campaign to remove homeless people from public space was sparked because local business people were tired of their "constant defecating, urinating" (Mitchell \& Staeheli, 2006, p. 162).

Mitchell (1995, p. 118) notes that for the homeless, public space is the only space to "go to the bathroom, sleep, drink, or make love." Yet these private activities are seen as illegitimate when they are performed in public space. As Kohn (2004, p. 129) writes:

Many people feel disgust when they see someone sleeping, washing, or relieving themselves in a park or alley ... When discussing the issue of homelessness, commentators often overlook the basic fact that "everything that is done has to be done somewhere." If an individual has no private place to perform intimate bodily functions, these will have to be performed in public or they will not be performed at all. The latter, however, is not an option, because they are functions intrinsic to life itself. No amount of criminalization or harassment can prevent people from performing activities intrinsic to life itself.

Although Mitchell and Kohn center their analyses on the lack of access to private space, in many homeless encampments across the nation, people have been able to establish a small realm of privacy within a tent or a shanty. In these circumstances, it is not a lack of access to private space, but rather a lack of infrastructural access that denies the homeless the ability to perform "functions intrinsic to life." 
Loftus-Farren (2011) characterizes homeless encampments in the United States as akin to informal housing settlements in the Global South. Indeed, people living in similar housing conditions in Mumbai are considered "informally housed" rather than homeless (McFarlane, 2008). As LoftusFarren (2011, p. 1039) argues:

Tent cities develop along with a host of safety, sanitation, and habitability concerns. These concerns range from the absence of running water or proper means for sewage disposal to the structural stability of dwellings ... However, even considering the inherent limitations and problems of tent cities, the benefits of such encampments are also considerable, especially within the context of the current housing crisis. Tent cities are a relatively affordable temporary housing option.

Yet cities across the United States are championing the provision of housing subsidies for the "chronically homeless" while destroying informal housing in encampments because of sanitation concerns. Notably absent from policy agenda has been any effort to provide sanitation to homeless encampments. In their policy report, Tremoulet and Bassett $(2012$, p. 17) argue that displacement of homeless encampments is often necessary because "the site has significant health and sanitation issues as a result of its current use. When the current hazards are cleared, the problem is likely to reoccur because there are no resources to address sanitation needs on an ongoing basis." The authors cite lack of sanitation as a reason to destroy homeless encampments yet write off the installation of sanitation infrastructure as an impossible option.

Much of the academic and policy literature on US homelessness has overlooked the need for sanitation in encampments, and has instead championed housing rights for the homeless. Yet the situation in Fresno reveals that urban struggles around homelessness center on more than just access to housing. As with informally housed communities in the Global South, access to sanitation is a chief concern to many people living in Fresno homeless encampments, and is a primary axis around which marginalization occurs. By drawing on theory from the Global South to analyze a problem in California, this paper sheds light on the centrality of sanitation to homeless encampments in the United States and seeks to move past ideological stigmatization of encampments as unhygienic and worthy of destruction. These insights, in turn, speak to homeless people's struggles for their right to the city as more than just an individual right to the benefits of capitalist property relations. In the following section, I document the ways in which inadequate sanitation contributed to eviction practices in Fresno, before returning at the end of this paper to an extended discussion of the right to the city. 


\section{The Fresno evictions}

Fresno is nestled in the heart of California's Central Valley and has long been home to some of the nation's poorest communities. In 2012, with an estimated homeless population of 5,135 people, Fresno had the secondhighest rate of homelessness in the nation (The National Alliance to End Homelessness, 2012). For more than a decade, the majority of homeless Fresnans did not have access to shelters. Many took refuge in sprawling homeless encampments concentrated in the city's downtown neighborhoods, where they lived in tents and shanties without access to running water, sewage, or trash facilities. In response to widespread homelessness, Fresno engaged in two contradictory, yet interrelated policy initiatives: it bulldozed informal homes while providing housing subsidies to a select few homeless residents.

Beginning in 2004, the Fresno police, along with the Sanitation Department, initiated their aggressive policy of bulldozing homeless encampments. Over the course of a 2-year period, the city conducted at least 50 evictions (Kincaid et al. v. City of Fresno, 2006). By 2006, the city was bulldozing a particular encampment on E Street every 2 weeks. During the raids, bulldozers came at odd hours and crushed everything in the camps, including animals, identification cards, birth certificates, medicine, shop-ping carts, wheelchairs, and medical records (Kincaid et al. v. City of Fresno, 2006). Over and over again, people lost the few worldly possessions they owned. One man who worked doing bicycle repairs lost twelve bikes and countless tools. Another man told me he was forced to sleep on the sidewalk with nothing but a blanket borrowed from a friend. On another occasion, a bulldozer nearly destroyed a man's tent while he was sleeping inside of it. The city's policies resulted in countless similar personal tragedies. As one homeless woman put it: "some people may be dirty ... [but] every little thing that a person has out here means a lot to them. And the way I see it, you wouldn't want somebody going to your house and just tearing it down with everything in it."

In 2006, hundreds of homeless Fresnans, represented by the American Civil Liberties Union, filed a class action lawsuit against the city. In December of that year, the district court granted the plaintiffs' request for an injunction, forcing the city to cease its bulldozing practices. During this temporary reprieve, encampments were able to grow and develop. The city ultimately settled with the plaintiffs for $\$ 1.4$ million. But in 2009, Fresno's new mayor, Ashley Swearengin, pledged to shut down the city's largest encampments. The next month, city police and sanitation crews came into the tent cities with bulldozers and razed them to the ground (National Coalition for the Homeless, 2010). 
Fresno's bulldozing practices can be seen as part of its rush toward a sanitized downtown space. As the city sought to turn downtown Fresno into an attractive destination, officials increasingly relied on a discourse of hygiene to justify removing homeless people from public space. As one local activist put it: "They would like [the homeless] to be gone. They're a blight ... If you walk down the street and you smell urine coming from each of the doorways, that doesn't make your city look good ... [The mayor] is more concerned with how things look than with making a difference." In Fresno, economic revitalization was inseparable from stigma against those without access to sanitation.

Rather than treating sanitation concerns as a reason to ameliorate conditions in the camps, public officials in Fresno used sanitation as a pretext to justify bulldozing practices. In defense of the class-action lawsuit, the city argued the evictions were necessary to address "health and sanitation" concerns (Kincaid et al. v. City of Fresno, 2006, pp. 5, 63). In an official press release praising the evictions, the city wrote: "The cleanup efforts are being conducted to address health and safety concerns" (City of Fresno, 2011). Local news media agreed. The Fresno Bee, Fresno's largest print news source, wrote in an editorial, "The city of Fresno is doing the right thing by clearing the multiple homeless encampments in or near downtown. These camps are filthy, unhealthy, dangerous and a blight on surrounding neighbors and businesses" (Editorial, 2013).

Local news media, public officials, and service providers described the encampments as "trash." Reporting on the evictions, The Fresno Bee described how "city sanitation crews scooped up piles of trash from about a dozen homeless encampments" (Galvan, 2006). The story ignored the shanties, tents, and countless valued possessions that were also destroyed. One shelter operator told me it was "absurd" that the homeless claimed they lost valuable possessions in the evictions. Another shelter operator described the evictions as trash pick-ups:

You got all this trash and mess, so when the city came in they started picking up all this stuff and throwing it away. Well the ACLU came in and said-They're throwing away your stuff. They can't do that. Even though it's trash, and everybody knows its trash ... People were saying - They threw away my passport. They threw away my driver's license. They threw away cherished mementos. They threw away my teeth. They threw away family ashes. And that's so untrue .... It just became a huge shanty town. Just one horrific mess.

The Fresno Bee quoted another local homeless service provider stating: "The trash is what you would see in Third-World countries ... This is truly a health hazard to our community" (Lee, 2013a). Over and over again, service 
providers and news media characterized homeless people's cherished possessions as unsanitary waste material.

The city also incorporated the rhetoric of trash into its official policy. In its decision on the class-action lawsuit, the district court wrote that, "The City's policy is that any property that is not physically attended to by its owner is considered abandoned and is defined by the City as "trash"' (Kincaid et al. v. City of Fresno, 2006, p. 13). This rhetoric is also recognized on the streets. One young homeless woman said the city treats the camps "like a dumpster that people live in ... They don't see it as somebody's home. They see it as garbage that was just put together. Trash." This language undermines the fact that countless homes were destroyed and that camps were in desperate need of garbage services.

In addition to being characterized as trash, encampments were also described as disgusting. In defense of the class action lawsuit, the city claimed: "The areas where homeless individuals live typically reek of urine and feces ... human sewage, syringes, used condoms, rotting food, and piles of trash and debris" (Kincaid et al. v. City of Fresno, 2006, p. 13). In 2012, a local TV station ran a story called "Filthy homeless encampment stinking up Fresno" ("Filthy homeless," 2012) and the same day The Fresno Bee blasted a similarly inflammatory headline on its front page- "Homeless encampment in Fresno a filthy, stinky eyesore" (Jiminez, 2012). In another story, local news reported: "Some call it disgusting, others say it's just plain wrong, and is a biohazard that is out of control" (Rosales, 2013). People also characterized the homeless themselves as disgusting. One shelter operator told me that he had "hosed down" a homeless man who came to his shelter: "It was horrible. He stunk ... He was living like a troll up on one of the bridges." This characterization of a man as a "troll" who needed to be "hosed down" reveals the power of sanitation discourses to turn human beings into objects of disgust, and violence against them into cleanliness.

As a corollary to this rhetoric of disgusting trash, the word "clean-up" became common parlance for eviction in Fresno (see City of Fresno, 2012; Kincaid et al. v. City of Fresno, 2006; Lee, 2013a; Rhodes, 2006). As the head of one homeless shelter told me, he encouraged the city to "clean up" the encampment that was a "gauntlet" in front of his shelter. In reality, he was urging the city to completely demolish the camp. After the city bulldozed all of the downtown camps in 2006, The Fresno Bee ran the headline: "Cleaning house-Fresno crews descend on downtown area to tidy up a haven for homeless." A local newspaper reported that one police officer said of the raids: "The homeless people that live here are the luckiest homeless in Fresno. They have maid service. We come out and clean up for them about every other week" (Rhodes, 2006). By replacing the words "bulldoze" and "demolish" with the unoffending phrase "clean up," officials 
concealed the violence of the evictions and portrayed them as sanitary and helpful.

In addition, the rhetoric of disgusting trash placed blame for unsanitary conditions squarely on the shoulders of the local homeless, and entirely ignored the lack of sanitation infrastructure. In one article, The Fresno Bee quoted a local resident saying, "I don't mind if they stay there, if only they cleaned up after themselves" (Galvan, 2006). Another article quoted a neighborhood resident saying "I'm sorry they're homeless, but that doesn't mean you have to be a slob" (Jiminez, 2012). This discourse existed in political circles as well. When I asked a local councilman what he thought about the evictions, he responded, "you've seen the filth, you've seen the vermin, the feces." He then told me the story of a business owner who photographed a homeless man defecating:

I think he probably just finished [defecating] when they came out and took his picture. And the guy's standing there [in the photo]... The body is defiant but the eyes are embarrassed... That alley is in jeopardy, because homeless people go, and they camp out there. And it comes with the filth and the public health problems that they bring with them ... They use the bathroom and they relieve themselves in the corner of the building ... As a councilmember I say, I don't care about the homeless, we need to make sure that this guy's business is safe and clean.

The councilman blamed homeless Fresnans' unhygienic practices for making them unpopular amongst his electorate, and felt that he had to vote against homeless interests in order to get re-elected. Yet he neglected the option of providing a place for homeless people to go to the bathroom or dispose of trash, and instead surmised that the man photographed was probably defecating because of a personal vendetta against the business owner.

In a particularly unrestrained moment, a shelter operator I spoke with criticized the city for not being more proactive in removing the homeless from downtown:

[The homeless] didn't care about all the trash being strewn all over the street ... People from all out of town come here ... What do they see? Nothing but shanty towns. I've had missionaries that come here and say I've been to Africa. I've been to other countries ... This is the same thing that I've seen in other countries, and this is America. And you have opportunities ... and they still live that way? ... We haven't taken the bull by the horns, and get a backbone, and say we're not going to allow you to do this. 
The shelter operator blamed the homeless for their conditions, explicitly connecting the encampment to informal housing in the Global South and engaging in precisely the same rhetoric that Chatterjee (2004) identifies in the context of Mumbai slums.

As with informal settlements in cities in much of the Global South, encampments in Fresno were not simply subject to material deprivation, but also the stigma that accompanied it. Just as Mumbai squatters were viewed as problems rather than citizens (Chatterjee, 2004), homeless Fresnans were similarly blamed for sanitation problems in the encampments. Further, as with the term "rubbish" used to describe informal housing in Zimbabwe, the Fresno encampments were also delegitimized as a form of housing and characterized as "trash" that must be removed for the improvement of the city.

Meanwhile, as the city tore down informal homes in the encampments, it simultaneously championed a politics of housing rights that would address the needs of a select few homeless residents. In 2008, with an influx of federal grants, Fresno adopted its 10-year plan to end chronic homelessness. The plan followed the federally promoted "housing first" model of securing housing for the "chronically homeless" without treatment prerequisites (Tsemberis, 2010). "Housing first" relies heavily on a public-private partnerships and private market rental properties (Del Casino \& Jocoy, 2008; Sparks, 2012). In Fresno, the plan called for a strategy of securing housing subsidies for 941 chronically homeless people over a 10-year period (Culhane \& Metraux, 2010). This number represented less than a fifth of Fresno's total homeless population, as the majority of people living in encampments were not considered "chronically" homeless. In addition to private rentals, the plan involved the development of the notoriously expensive "Renaissance" housing projects. As one homeless man told me about the project: "I think that's kind of a waste of money, to tell you the truth ... because you don't even have maybe a handful of homeless people just in there."

Others recognized that the provision of housing did not solve the problem of homelessness. As one man reflected on the possibility of receiving a housing voucher: "That's one less person on the streets. What about everybody else? ... It's still a concern, whether you leave, whether I leave, it's still a concern out here." He recognized that, without tackling the underlying problems that lead to the poverty and dispossession, no amount of housing provision will solve the problem of homelessness. Nonetheless, as a result of its "housing first" initiative, the city was able to secure millions of dollars in federal stimulus funds (Fresno City Hall, 2010). These funds were redistributed to housing developers and landlords in the form of developer fees and subsidized rental payments, rather than addressing homeless people's selfidentified need for sanitation infrastructure in the encampments. 
As the following section documents, homeless Fresnans struggled for years to install informal infrastructure in their encampments, with some success. Yet they found themselves in a double-bind: their lack of infrastructure perpetuated the stigma that supported the evictions, and the evictions destroyed whatever basic infrastructure they were able to achieve. Although the evictions temporarily dispersed the problems of sanitation, they ultimately aggravated the infrastructural deprivation, which created an ongoing cycle of exclusion and dispossession in the lives of homeless Fresnans. The following section reveals the centrality of sanitation to Fresno homeless resistance, and begins by highlighting similar sanitation struggles in encampments across the United States.

\section{The struggle for sanitation}

Scholars have documented a long history of homeless encampments functioning as sites of resistance (DePastino, 2003; Mitchell, 2012). Tent cities today often provide homeless people access to unpoliced space and an opportunity to voice their political demands (Mitchell, 2012; National Coalition for the Homeless, 2010; Ruddick, 1996). Beyond Fresno, homeless campers have demanded greater access to urban infrastructural services, and have struggled to maintain a modicum of sanitation in encampments. In San Jose, California, sanitation was a primary concern to tent city residents (Bridegam, 2014). Similarly, Love Camp in Los Angeles pooled resources to rent portable toilets (Ruddick, 1996) and Dignity Village sought to create compost toilets as an alternative form of sanitation (National Coalition for the Homeless, 2010).

In Sacramento, California, a homeless resistance movement emerged in response to a "sanitation crisis" in a riverbed encampment (Watters, 2012, p. 272). Local business owners and community members described the homeless in Sacramento as "shameless" and "filthy" for urinating and defecating in public $(2012$, p. 83). Yet people living in the encampment had to walk a mile and a half to the nearest drinking fountains to get water, and it was nearly impossible for them to find a place to shower. There were no nearby public restrooms, and local businesses refused to allow them to use the facilities. Watters writes:

This situation leaves little choice for many of the homeless except to use the outdoors to relieve themselves, and that is not without concern. One camper shared, "I have, on occasion encountered difficulties with the need to take care of my bodily functions. You can't let anyone see you ... It is very stressful." (2012, pp. 271-272)

In response to this crisis, local homeless people successfully advocated for portable toilets in the encampment. After a flood destroyed the toilets, "a 
campaign of harassment was launched by the county officials, rangers and eventually the local media to get all the homeless off the American River Parkway" (2012, p. 272). When campers again installed toilets, the city removed them after complaints of "homeless infrastructure" on the river (2012, p. 275). In response, one member took it upon himself to create a "sanitary toilet system" that involved collecting waste from a makeshift toilet. He said of the experience: "The first few times it was horrible, it's a difficult job but someone's got to do it and it is worthwhile, absolutely...The women really appreciate it. We all do because we are re-humanized, because we're not just thrown aside" (2012, p. 276). Yet local authorities "purposely resisted attempts to provide improved sanitation to the homeless ... and the dreaded homeless infrastructure they seek to avoid" (2012, p. 278). As in Fresno, the struggle over homeless rights in Sacramento became a struggle for sanitation infrastructure.

In Fresno, campers' concerns centered on sanitation. Tent city residents worked hard to maintain a clean space. One woman constructed a shanty with separate rooms for showering and using the bathroom. Another tent city resident said of her community, "The streets have been kept cleaner than they've been in two decades, believe it or not. Who does that? We do. We sweep the drains. We clean the drains. We keep the trash up out of the street" (Kennedy, 2011). Another homeless woman insisted that the homeless ensured the continued cleanliness of the portable toilet in their encampment.

In describing her use of Circle K mini-mart bathrooms, she said, "I left it better than when it was when I went in there." Wright (1997, p. 255) argues that for homeless people, the very act of creating a clean place to sleep "contributes to the redefinition of that space, especially in the eyes of authorities who wish to maintain a 'proper' version of space." This creation of clean domestic spaces challenged the city's rhetoric of street camps as unhygienic and thus worthy of destruction.

Personal hygiene was also a high priority for many of the homeless people I spoke with. One young woman explained the importance of hygiene to her daily routine of panhandling and hustling:

We didn't want to be viewed as homeless, more as people ... I would shower in McDonald's ... Wash my hair in the sink, sponge bath ... Whenever we got a hotel we'd use that time to hand wash all of our things ... If I'm looking put together then I'll feel better about myself then I'll have more game.

Although she didn't like to steal, "it got to the point sometimes where you're just like-I want to stay in a hotel room. I want a bath." Another woman said the thing she missed the most living on the streets was easy access to showers. Her biggest hope was to get "back into a four-walled situation 
where I can have a shower whenever I want to. I'll probably be in the shower for like two weeks." Another man described himself as a "hygienist freak," which made it especially difficult to be homeless. When his tent was destroyed in an eviction, his first concern was how he would take a shower and change before going to work the next morning. The daily struggle to maintain hygienic living conditions belies the stigmatizing rhetoric of the encampments as fundamentally unsanitary spaces.

One homeless woman I spoke with advocated for improvements to sanitation as an alternative option to eviction:

If there's something about it you don't like-you say it's too nasty, too dirty - find a way to clean it up ... If there's a problem with garbage or anything like that, find a way to work it out ... If there's something about it you don't like, help us to make it better for you. But don't just take our stuff away because you don't agree with it or you don't like it, and leave us with nothing ... Say you were on the streets. What are you going to do? You're going to find a tent ... You going to build up on some clothes, some hygiene, get some food, straighten up ... So I don't think they have the right to judge when they'd be doing the same thing in the same situation.

Her vision of a more ethical policy toward the homeless involved improvements to her camp to "clean it up" rather than eviction or placement in housing facilities. She also emphasized the importance of getting "some hygiene" for people living on the streets. Many people understood that the lack of sanitation infrastructure and trash services was the biggest obstacle preventing homeless people from improving their encampments. As one local activist put it: "Some of the encampments were almost nice. If they put in Porta-Potties and trash bins, they would've been nice."

The struggle for sanitation also took the form of continued political action. In 2007, homeless activists and allies demanded the installation of toilets and trash facilities for Fresno's largest tent city (Rhodes, 2007a). The Police Department issued a memo urging the city not to install toilets, because of fear of crime occurring inside the facilities. Several council members voiced similar concerns (Rhodes, 2007b). The city ignored the need for sanitation infrastructure in favor of its dual policy of tent city evictions and housing vouchers. As one activist told me:

Many of those people that got the initial vouchers have since found themselves back on the street. But in the meantime the City of Fresno insists that that is their only policy on dealing with the homelessthat they are not going to provide any resources for their immediate needs, or mid-term needs. What we wanted them to do is to provide immediately portable toilets and trash bins and drinking water right 
where they are so that they could survive ... But this city will do nothing on the immediate front ... And to me, it's just the right thing to do because everybody should have the dignity and respect of a place to go to the bathroom, and drinking water, and a place to throw their trash ... Their policy has been to evict people, move them on from place to place and not provide any basic services for them while they're out there ... They will only move people into housing.

As another activist lamented: "You bring in trash containers and PortaPotties - it's gonna make life much better. But again the city isn't very cooperative with that." At the urging of a councilmember who voiced concerns about local business interests, the city eventually installed three portable toilets in one of the encampments. ${ }^{2}$ As one activist told me, the city finally acquiesced because "it took pressure off the neighboring businesses and residential area ... And that lasted for a while, and they eventually dismantled it, and they kicked everybody out of that encampment, and they hauled that stuff away, and they never did it again."

In 2011, homeless campers protested again. More than a hundred people camped out overnight at City Hall to demand trash bins, portable toilets and fresh drinking water for Fresno tent cities (Williams, 2011). Alphonso Williams, a local homeless man, wrote about the event in the local alternative newspaper:

Of our three requests - for trash bins, portable toilets and fresh drinking water - we hope to at least have a trash bin in place at the Santa Clara and E street encampment by the time you read this ... Homeless advocates, along with advocates who are homeless, came from as far away as Sacramento, San Jose, Merced and San Francisco in support of this Human Rights Day event and to join the Fresno advocates and supporters of the action to request that the City of Fresno provide trash bins, portable toilets and fresh drinking water at the homeless encampments in downtown Fresno as mandated by the Universal Declaration of Human Rights. (Williams, 2011)

Thus, homeless protesters engaged a discourse of human rights in demanding access to sanitation. Yet this time, the city did not respond, and the homeless took another tactic.

In conjunction with homeless Fresnans, a local activist movement organized a group that periodically helped to clean trash in the encampments. They raised money to install and service four dumpsters and ten portable toilets at

\footnotetext{
${ }^{2}$ As an odd corollary, the mayor insisted on hiring a private security force to monitor the toilets $24 \mathrm{~h}$ a day, costing the City $\$ 13,000$ per month (Rhodes, 2007c).
} 
encampments across town. Local alternative news media reported on the effort:

Because the City of Fresno has refused to help provide the homeless with drinking water, trash bins or portable toilets, it has become necessary for individuals and groups to do more. Spokespersons for the city say they are focusing on finding housing for the homeless and don't want to be distracted by providing services for the thousands of homeless people living in the city. They acknowledge that there are more than 4,000 chronically homeless people in Fresno and point to the Renaissance housing projects that house a little more than 100 persons as an example of their contribution to end homelessness. (Rhodes, 2013)

One homeless man called the portable toilets in his camp a "blessing." $\mathrm{He}$ said, "It's very helpful, especially for the ladies" (Lee, 2013b). Another woman told me the portable toilet in her encampment was "heaven sent." By building alternative infrastructures in the encampments, homeless Fresnans and activists collectively created new city spaces that reflected their own interests and demands. As shown in the section below, this move was a crucial step in remaking urban infrastructure and struggling against the exclusionary politics of sanitation.

Yet the community funded trash bins were not sufficient. Despite their willingness to bulldoze entire encampments, the city refused to pick up trash or to install additional trash bins in the camps. City officials cited previous lawsuits for their continued refusal to install trash facilities. As the Fresno Assistant City Manager said, "If we go out there, and we have gone out and cleaned up what people perceive and we agree is junk, we end up being on the end of lawsuit, claiming that we threw away someone's personal valuable processions" (Rosales, 2013). As one activist told me, "They cite, we don't pick up the trash, because you guys sue us every time we do. As if that was the same thing - picking up the trash was the same as bulldozing encampments." Another advocate said, "If we can help keep the encampments clean without destroying homeless people's property, why can't the city do the same thing?" Again, the city argued that the encampments themselves were trash, which made it impossible to clean them without destroying them completely.

The portable toilets were insufficient meet the needs of the thousands of homeless Fresnans. A local advocate told me the portable toilets were "totally inadequate. There needs to be probably three times that many. But it's something that does take the edge off of it a little bit." Nonetheless, the city continually refused to provide sanitation infrastructure to the camps. Other options were few and far between. Activist allies continually struggled to secure toilet paper donations for the homeless and also sought to install 
compost toilets in the encampments. The local Rescue Mission did not let people take showers unless they were enrolled full-time in their drug treatment program. One homeless woman told me that the Mission refused to let her use their bathroom even when she was pregnant: "I went over there one time. I told them-Can I use the bathroom real quick? I'm pregnant, I have to go. They told me no, to where I had to go outside." Another woman told me that every time she wanted to use the bathroom, she had to make sure she had enough money to purchase something from the local mini-mart, or risk not being allowed to use its facilities. Homeless people often purchased food in order to use the bathrooms in fast food restaurants. Yet in 2007, an incident at McDonald's sparked a struggle over the privatization of their facilities.

On this occasion, a McDonald's manager refused a disabled homeless woman access to their bathroom because she "wasn't purchasing anything" (Rhodes, 2007c). When the woman asserted her right to use the bathroom, she was arrested for "interfering with business." Thus McDonald's advocated a position in which sanitation provision was only available in exchange for money. Days later, homeless people and advocate allies staged a protest to demand access to McDonald's bathrooms. They held signs that read "McDiscrimination," "I'm Not Lovin' It," "Homeless Go Home," and "Normal People Only" (Rhodes, 2007d). A local homeless man said: "McDonald's has started discriminating against the homeless and handicapped people ... we are going to make this public" (Rhodes, 2007d). In the context of the struggle for sanitation infrastructure in Fresno, the homeless demanded that publicly available restrooms belong to all residents of the city, without the requirement of payment. As outlined in the discussion below, this demand for decommodified infrastructure speaks directly to Henri Lefebvre's conception of the right to the city, and serves as a potent reminder of the distinction between policy solutions and radical urban struggles.

\section{Housing, infrastructure, and the right to city}

For Henri Lefebvre (1996), the right to the city resists the homogenous and commodified urban landscape that is produced through capitalist growth. It is the urban dweller's "cry and demand" that emerges from the chaos and unpredictability of the street to reclaim city spaces. But the right to the city is not just about access to urban resources or spaces. It does not demand inclusion in an unequal and exploitative system, but rather a complete overhaul of the system itself (Mayer, 2012). It is the creation of urban space not as an object of exchange but as an oeuvre - a creative collaboration. As Harvey (2008) urges, it "inevitably depends upon the exercise of a collective power to reshape the processes of urbanization" (2008, p. 23). Within this 
collective, Marcuse (2009, p. 190) argues that the right belongs to the culturally alienated, as well as the materially deprived - "those directly in want, directly oppressed, those for whom even their most immediate needs are not fulfilled: the homeless, the hungry, the imprisoned, the persecuted." Often subject to extreme forms of dispossession, the homeless certainly have a great stake in reclaiming the city.

In activist circles, the right to the city has been used to advocate for housing rights for the homeless (Olds, 1998; Right to the City, 2013). The World Charter for the Right to the City affirms that all homeless people have a "right to adequate housing" (World Social Forum, 2005, p. 8). In academia, a wide range of scholars have advocated for a fundamental right to housing for the homeless (Bratt, Stone, \& Hartman, 2006; Foscarinis, 2005; Foscarinis, Paul, Porter, \& Scherer, 2004; Hartman, 1998; Michelman, 1970; Thiele, 2002). Much of the critical literature on homelessness today remains loyal to the paradigm of housing rights, and many have championed the "housing first" model as a progressive trend in US politics (Tsemberis, 2010).

Yet others have argued that the right to housing is not sufficient, in and of itself, to ending homelessness. As Engels (1935) observed more than a century ago in The Housing Question, bourgeoisie housing reform ignores the problem of capitalist inequality. By focusing solely on housing in isolation from larger demands, advocates undermine the radical potential of the right to the city. As Mitchell (2003, pp. 19-21) urges, the right to housing is not enough:

The right to the city implies the right to uses of city spaces, the right to inhabit ... a place to sleep, a place to urinate and defecate without asking someone else's permission, a place to relax, and place from which to venture forth ... the right to inhabit the city, thus demands more than just houses and apartments: it demands the redevelopment of the city in a manner responsive to the needs, desires, and pleasure of its inhabitants, especially its oppressed inhabitants.

Thus, the "right to housing" formulation reduces the right to inhabit the city into a mere right to a habitat. Pindell (2006, p. 439) expresses a similar sentiment, arguing that the right to the city "is not as pithy as guaranteeing all persons shelter."

Housing-based interpretations of the right to the city also come with a set of spatial concerns. Lefebvre (1996) urged that the right to the city is not isolated or segmented. Rather, it enables the dispossessed to reclaim "the use of the center, a privileged place, instead of being dispersed and stuck into ghettos" (Lefebvre, 1996, p. 34). Yet De Souza (2010) argues that the right is often reduced to a "politics of turf" that presents a low horizon for grassroots activism (2010, p. 318). Purcell (2002) highlights a related contradiction in 
how the right to the city operates at urban "sub-scales." While collective control at the neighborhood scale can easily result in a ghettoized and uneven urban landscape, it is nonetheless essential for marginalized groups to maintain control over their own neighborhoods in order to prevent powerful outsiders from undermining their autonomy (Purcell, 2002).

These scalar problems can be extended to the question of housing rights. The provision of housing for the homeless can be seen as the extreme manifestation of "turf" politics, in which individuals are assisted in securing their own domestic spaces while the larger problem of capitalist housing remains unchallenged. Further, if the urban collective has the right to determine the form of domestic space of each resident, then marginalized residents can be forced into unwanted domestic situations and denied any realm of privacy beyond collective control. This problem has implications for the homeless in particular, who have been historically subject to the whims of hostile majorities (Attoh, 2011). On the other hand, if the right to the city operates at the scale of the household, it can easily devolve into the individualized rights to housing that Mitchell (2003) and others critique. In light of such concerns, it is unclear what the right to the city looks like for the homeless, who suffer first and foremost from a lack of housing. It is clear, however, that remaking the city requires more than the provision of individual units of housing, and includes the struggle to detach domestic needs like shelter, water, and sanitation from the bonds of private property. As the situation in Fresno reveals, the struggle for sanitation infrastructure is an essential step in this direction.

Unlike government provision of housing — which ameliorated hardships of homelessness for a select few Fresnans - the struggle for sanitation in Fresno was not simply ameliorative or individualized. The struggle for the right to the city is the struggle for the city, in its entirety, including its vast network of infrastructural amenities. By building alternative infrastructures in the encampments, homeless Fresnans and activists collectively created the encampment as an ouevre that reflected their own interests and demands. Further, in demanding public provision of infrastructure and resisting privatization of for-profit urban infrastructure, they sought to redefine the city at large. Infrastructure consists of more than just spatially contained units, and includes a vast network of flows between structures in the built environment. Indeed, the built form of the city itself can be understood as a system of infrastructures (Graham \& Marvin, 2001). To truly inhabit the city, the homeless in Fresno sought to create a new understanding of sanitation infrastructure as belonging to all urban inhabitants. By demanding those domestic needs that are located beyond the scale of the home or the neighborhood, and that constitute the functioning of the city as a whole, they avoided the trap of individualized solutions and "turf" politics. Instead, they adopted a struggle that would fundamentally challenge the functioning of 
privatized capitalist infrastructure and decommodify domestic needs in the city at large.

Beyond this, infrastructural provision is essential to the notion of housing itself. Gandy (2005, p. 28) argues that an integrated system of urban infrastructure creates an "exoskeleton for the human body with its provision of water, warmth, light and other essential needs." This "exoskeleton" is composed of a complex system of "networks, pipes and wires that enable the modern city to function." Thus, the home is not only the structure of the house itself, but its connection to the world of urban infrastructure. This notion of home as infrastructure reframes the struggle for housing in the encampments as a struggle for greater access to infrastructure. Crucially, this demand for a radical re-envisioning of urban infrastructure avoids the potential for the hostile collectives to control the private space of homeless residents.

An additional scalar concern involves the need to move beyond local or national projects to address the problem of global capitalist inequality. Mayer (2012) argues that right to the city movements in the Global North often become co-opted by the project of neoliberal urbanism. In particular, efforts to reclaim autonomous urban spaces are easily incorporated into the development of fashionable and upscale neighborhoods and cities. This, in turn, further entrenches the stark inequalities between privileged cities in the Global North and urban dispossession in the Global South. Thus, in overlooking the global scale of right to the city struggles, movements in the Global North can inadvertently reinforce large-scale patterns of uneven development. Mayer (2012) argues for greater understanding of right to the city struggles in the Global South-emerging from favelas, shack towns, and slums in particular - in order to create North-South solidarities. A first step in this direction is to identify continuities between urban movements across the globe. As the situation in Fresno reveals, the struggle for infrastructure might provide one such point of continuity.

In arguing for infrastructural rights, I do not wish to imply that housing rights are inherently problematic. Indeed, the provision of subsidized apartments ended homelessness in the lives of many Fresnans. But often such ameliorative solutions simply defer the fundamental contradictions of capitalism - in this instance, by reintegrating homeless people into the landscape of private property - rather than challenging the underpinnings of capitalist urbanism itself. The lesson from Fresno is not that housing rights are secondary to infrastructural rights, but rather that truly radical housing rights move towards decommodifying domestic life itself. Mayer (2012) highlights how radical housing struggles in cities across the United States have sought to challenge the legal frameworks of private property. In the sense that law itself is part of the state's infrastructural apparatus (Meehan, 
2014), radical housing struggles do not simply seek to claim private domestic space, but to transform the legal infrastructures of capitalist housing.

In focusing on infrastructure, I also do not seek to naturalize the encampments as a final and complete solution to the problem of homelessness. Rather, my primary aim is to return to the demands emerging from the street. More than anything else, Lefebvre's discussion of the right to the city is marked by his critique of urban planning. He emphasizes the limitations of institutionalized planning efforts and writes that only "social life" can create a new city: "The architect, the planner, the sociologist, the economist, the philosopher or the politician cannot out of nothingness create new forms and relations ... Only social life (praxis) in its global capacity possesses such powers" (1996, p. 151). Thus, Lefebvre calls for a new approach to reclaiming the urban - through experiment and practice rather than blueprints on a planner's desk. In Fresno, homeless campers consistently demanded access to sanitation infrastructure, or, as Mitchell (2003) writes, "a place to urinate and defecate without asking someone else's permission."

In emphasizing that the right to the city emerges from the social collective, Lefebvre (1996) stressed that the radical visions are often foreclosed by technocratic solutions. Indeed, the search for solutions often erases the fact of ongoing grassroots struggle. This, in a sense, is another scalar aspect of the right to the city - in which time is the key lens of analysis. The right to the city is not enacted overnight or even over the course of years, as the history of capitalist urbanization itself is the history of the right to the city. The situation in Fresno reveals that the right to the city is part of the long historical process of struggling to overcome pressures inherent to capitalist relations, and that in some instances, what appear to be stop-gap measures are in fact the most crucial and immediate lines of struggle in the ongoing project of remaking the city. In this sense, an effort that appears unambitious in the moment - the provision of sanitation to homeless encampments - can be seen from a broader temporal lens as the beginning of a move towards untying the bonds between private property and domestic life.

Finally, the struggles in Fresno reveal that the right to the city is not only a material struggle, but also an ideological one. Lefebvre argued that technocrats tend to produce a sanitized urban space and "despise odors" for being "incongruous, incontrollable, archaic." Instead, they prefer "to have everything pasteurized, everything hygienic and deodorized" (Merrifield, 2006, p. 90, citing Lefebvre, 1971). In Fresno, homeless campers resisted official efforts to produce a sanitized city and refused the ideological oppressions waged against those without access to sanitation. The struggle for sanitation grounds discourses of the "filthy other" in the actual material conditions of infrastructural inequality. Further, it highlights the dangers of capitalist ideologies of private property that relegate of non-conforming 
homes to the category of "trash." In this way, the right to the city is the right to a new understanding of urban space.

\section{Conclusion}

For many living in informal housing in the Global South, ideological and material exclusion often center on a lack of infrastructural access. This article has sought to reveal that homeless people living in encampments in the United States similarly struggle with inadequate sanitation, and are subject to stigma and eviction as a result. Yet by and large, mainstream understandings of homelessness in the United States have rejected encampments as improper forms of shelter, and officials have focused on the provision of private housing while ignoring the collective and pressing need for sanitation. In contrast to individual rights to housing, the right to the city presents a more radical framework for homeless struggles centered on homeless people's agency to remake the city. In this framework, the right to the city is not an ameliorative or technical solution, but an ongoing and incomplete struggle to establish a new way of being in the city. By examining homeless encampments in the larger context of global informality and capitalist urbanization, this paper hopes to call attention to the centrality of infrastructure in the project of creating more egalitarian and inclusive cities. 


\section{References}

Anderson, Warwick (1995). Excremental colonialism: Public health and the poetics of pollution. Critical Inquiry, 21(3), 640-669.

Attoh, Kafui (2011). What kind of right is the right to the city? Progress in Human Geography, 35(5), 669-685.

Bratt, Rachel, Stone, Michael, \& Hartman, Chester (Eds.). (2006). A right to housing: Foundation for a new social agenda. Philadelphia, PA: Temple University Press.

Bridegam, Martha (2014). Hydraulics of homelessness: Stormwater challenges are linked to encampments in San Jose. California Planning and Development Report. Retrieved from http://www.cpdr.com/node/3495

Chatterjee, Partha (2004). The politics of the governed: Reflections on popular politics in most of the world. Delhi: Permanent Black.

City of Fresno. (2011). City crews complete cleanup of encampments near Monterey Street Bridge-Federal official commends City of Fresno, partners for working toward long-term solutions to homelessness. Fresno, CA: City of Fresno.

City of Fresno. (2012). Federal report shows Fresno, Madera counties with 4th-largest decrease in total homeless from 2011 to 2012 - Mayor Swearengin: Partnerships are 'producing results'. Fresno, CA: City of Fresno.

Culhane, Dennis, \& Metraux, Stephen (2010). Development of Cost Analysis of the City and County of Fresno's Ten-Year Plan to End Chronic Homelessness: Preliminary Estimates Using Existing Data and Recommendations for Full Evaluation Strategy [report commissioned by the City of Fresno].

De Souza, Marcelo Lopes (2010). Which right to which city? In defence of political-strategic clarity. Interface, 2(1), 315-333.

De Venanzi, Augusto (2008). The institutional dynamics of homelessness: The United States of America and Japan compared. International Journal of Sociology and Social Policy, 28(3/4), 129-145. 
Del Casino, Vincent, \& Jocoy, Christine (2008). Neoliberal subjectivities, the "new" homelessness, and struggles over spaces of/in the city. Antipode, 40(2), 192-199.

DePastino, Todd (2003). Citizen hobo: How a century of homelessness shaped America. Chicago, IL: University of Chicago Press.

Dunlap, David (1988). Koch, the "Entertainer," gets mixed review. The New York Times, May 19, p. B4.

Editorial. (2013). After camps are cleared out, what is next for homeless? The Fresno Bee, August 29 p. A12.

Edwards, Paul N. (2004). Infrastructure and modernity: Force, time, and social organization in the history of sociotechnical systems. In Thomas J. Misa, Philip Brey, \& Andrew Feenberg (Eds.), Modernity and technology (pp. 185-225). Cambridge, MA: MIT Press.

Engels, Friedrich (1935). The housing question. New York, NY:

International publishers.

"Filthy homeless encampment stinking up Fresno." (2012, July 20). San Jose Mercury News. Retrieved from http://www.mercurynews.com/california/ci 21118928/filthy-homelessencampment-stinking-up-fresno

Foscarinis, Maria (2005). Advocating for the human right to housing: Notes from the United States. New York University Review of Law and Social Change, 30, 447.

Foscarinis, Maria, Paul, Brad, Porter, Bruce, \& Scherer, Andrew (2004). Human right to housing: Making the case in U.S. advocacy. Clearinghouse Review, 38, 97.

Fresno City Hall. (2010, September 23). CityVision - First Steps Home [video file]. Retrieved from http://www.youtube.com/watch?v=QMLBG7EckYI

Galvan, Louis (2006). Cleaning house - Fresno crews descend on downtown area to tidy up a haven for homeless. The Fresno Bee, June 23, p. B1.

Gandy, Matthew (1999). The Paris sewers and the rationalization of urban space. Transactions of the Institute of British Geographers, 24(1), 23-44. 
Gandy, Matthew (2005). Cyborg urbanization: Complexity and monstrosity in the contemporary city. International Journal of Urban and Regional Research, 29(1), 26-49.

Graham, Steve, \& Marvin, Simon (2001). Splintering urbanism: Networked infrastructures, technological mobilities and the urban condition. New York, NY: Routledge.

Greenberg, Stanley, \& Garver, Thomas (1998). Invisible New York: The hidden infrastructure of the city. Baltimore, MD: Johns Hopkins University Press.

Hartman, Chester (1998). The case for a right to housing. Housing Policy Debate, 9(2), 223-246.

Harvey, David (2008). The right to the city. New Left Review, 53, 23-40.

Hunter, Julie, Linden-Retek, Paul, Shebaya, Sirine, \& Halpert, Samuel (2014). Welcome home: The rise of tent cities in the United States. National Law Center on Homelessness \& Poverty \& Allard K. Lowenstein International Human Rights Clinic. New Haven, CT: Yale Law School.

Institute for War and Peace Reporting. (2005). Clearance victims left in limbo. Retrieved from http://www.reliefweb.int/rw/RWB.NSF/db900SID/MIRA6E24C5?OpenDocument

Jiminez, Eddie (2012). Homeless encampment in Fresno a filthy, stinky eyesore. The Fresno Bee, July 20, p. A1.

Kennedy, Jean. (2011, October 26). Families of Fresno's tent cities [video file]. Retrieved from http://www.youtube.com/watch?v=fMil6wS5vd4\&feature=relmfu

Kincaid et al. v. City of Fresno. (2006). Statement of decision and findings re: Plaintiffs' application for a preliminary injunction. Fresno, CA: United States District Court, Eastern District of California.

Kohn, Margaret (2004). Brave new neighborhoods. New York, NY: Routledge.

Larkin, Brian (2013). The politics and poetics of infrastructure. Annual Review of Anthropology, 42, 327-343. 
Lee, BoNhia (2013a). Residents ask city to clean up trash. The Fresno Bee, March 14, p. A3.

Lee, BoNhia (2013b). Volunteers clean up Fresno homeless camps. The Fresno Bee, March 30, p. A1.

Lefebvre, Henri (1971). Vers le cybernanthrope: Contre les technocrats. Paris: Denoel.

Lefebvre, Henri (1996). The right to the city. In Eleonore Kofman \& Elizabeth Lebas (Eds.), Writings on cities (pp. 61-181). Oxford: Blackwell.

Loftus-Farren, Zoe (2011). Tent cities: An interim solution to homelessness and affordable housing shortages in the United States. California Law Review, 99(4), 1037.

Mair, Andrew (1986). The homeless and the post-industrial city. Political Geography Quarterly, 5(4), 351-368.

Marcuse, Peter (2009). From critical urban theory to the right to the city. City, 13(2-3), 185-197.

Mayer, Margit (2012). The "right to the city" in urban social movements. In Neil Brenner, Peter Marcuse, \& Margit Mayer (Eds.), Cities for people and not for profit: Critical urban theory andthe right to the city (pp. 63-85). New York, NY: Routledge.

McFarlane, Colin (2008). Governing the contaminated city: Infrastructure and sanitation in colonial and post-colonial Bombay. International Journal of Urban and Regional Research, 32(2), 415-435.

McFarlane, Colin, \& Rutherford, Jonathan (2008). Political infrastructures: Governing and experiencing the fabric of the city. International Journal of Urban and Regional Research, 32(2), 363-374.

Meehan, Katie (2014). Tool-power: Water infrastructure as wellsprings of state power. Geoforum, 57, 215-224.

Merrifield, Andy (2006). Henri Lefebvre: A critical introduction. New York, NY: Routledge.

Michelle, Kooy, \& Bakker, Karen (2008). Technologies of government: Constituting subjectivities, spaces, and infrastructures in colonial and 
contemporary Jakarta. International Journal of Urban and Regional Research, 32(2), 375-391.

Michelman, Frank (1970). The advent of a right to housing: A current appraisal. The Harvard Civil Rights-Civil Liberties Law Review, 5, 207.

Mitchell, D., \& Staeheli, Lynn (2006). Clean and safe? Property redevelopment, public space, and homelessness in downtown San Diego. In Setha Low \& Neil Smith (Eds.), The politics of public space (pp. 143-175). New York, NY: Routledge.

Mitchell, Don (1995). The end of public space? People's Park, definitions of the public, and democracy. Annals of the Association of American Geographers, 85(1), 108-133.

Mitchell, Don (1997). The annihilation of space by law: The roots and implications of anti-homeless laws in the United States. Antipode, 29(3), 303-335.

Mitchell, Don (2003). The right to the city: Social justice and the fight for public space. New York, NY: Guilford.

Mitchell, Don (2012). Tent city: Spaces of homeless survival and organizing in the American city. In Andrea Phillips \& Fulya Erdemci (Eds.), Social housing - Housing the social: Art, property, and spatial justice (pp. 277306). Amsterdam: SKOR and Sternberg Press.

National Alliance to End Homelessness. (2012). State of homelessness in America. Washington, DC.

National Coalition for the Homeless. (2010). Tent Cities in America: A Pacific Coast Report. Washington, DC.

Olds, Kris (1998). Urban mega-events, evictions and housing rights: The Canadian case. Current Issues in Tourism, 1(1), 2-46.

Pindell, Ngai (2006). Finding a right to the city: Exploring property and community in Brazil and in the United States. Vanderbilt Journal of Transnational Law, 39, 435.

Purcell, Mark (2002). Excavating Lefebvre: The right to the city and its urban politics of the inhabitant. GeoJournal, 58(2/3), 99-108. 
Rhodes, Mike (2006, June 22). Fresno homeless attacked and insulted by city workers. The Community Alliance Newspaper. Retrieved from: https://www.indybay.org/newsitems/2006/ 06/22/18281976.php

Rhodes, Mike (2007a, April 10). Mayor Alan Autry undermines the homeless. The Community Alliance Newspaper. Retrieved from https://www.indybay.org/newsitems/2007/04/10/ 18394028.php

Rhodes, Mike (2007b, May 15). The city of Fresno votes to install portable toilets for the homeless. The Community Alliance Newspaper. Retrieved from https://www.indybay.org/news items/2007/05/15/18416812.php

Rhodes, Mike (2007c, July 8). Homeless woman arrested at McDonald's. The Community Alliance Newspaper. Retrieved from https://www.indybay.org/newsitems/2007/07/08/ 18433984.php

Rhodes, Mike (2007d, July 15). Arrest sparks protest at McDonald's. The Community Alliance Newspaper. Retrieved from https://www.indybay.org/newsitems/2007/07/15/18435604.php

Rhodes, Mike (2013). The Community Alliance helps the homeless. The Community Alliance Newspaper, January 1.

Right to the City. (2013). New "Homes for All" campaign launches with national day of action in 11 major cities uniting homeless families, public housing residents, underwater homeowners, and renters, March 13.

Rosales, Erik (2013). Homeless trashy mess, city afraid to take action! KMPH News, May 15. Retrieved from http://www.kmphkfre.com/story/22266264/homeless-trashy-mess-city-afraid-to-do-anything

Roy, Ananya (2003). Paradigms of propertied citizenship: Transnational techniques of analysis. Urban Affairs Review, 38(4), 463-491.

Ruddick, Susan (1996). Young and homeless in Hollywood: Managing social identities. New York, NY: Routledge.

Sparks, Tony (2012). Governing the homeless in an age of compassion: Homelessness, citizenship, and the 10-Year Plan to End Homelessness in King County Washington. Antipode, 44(4), 1510-1531.

Sparks, Tony (2015). Citizens without property: Informal citizenship and governmentality in a U.S. homeless encampment. Manuscript submitted for publication. 
Star, Susan L. (1999). The ethnography of infrastructure. American Behavioral Scientist, 43(3), 377-391.

Thiele, Bret (2002). The human right to adequate housing: A tool for promoting and protecting individual and community health. American Journal of Public Health, 92(5), 712-715.

Tremoulet, Andrée, \& Bassett, Ellen (2012). Homeless encampments on public right-of-way.

Portland: Oregon Transportation Research and Education Consortium.

Tsemberis, Sam (2010). Housing first: Ending homelessness, promoting recovery and reducing costs. In Ingrid Gould Ellen \& Brendan O'Flaherty (Eds.), How to house the homeless (pp. 37-56). New York, NY: Russell Sage Foundation Publications.

UN Habitat. (2003). Water and sanitation in the world's cities: Local action for global goals. London: Earthscan.

Watters, Stephen (2012). Homelessness in Sacramento: Searching for safe ground (master's thesis). Sacramento: California State University Sacramento.

Williams, Alphonso (2011, January 1). Human rights day at City Hall. The Community Alliance Newspaper. Retrieved from http://fresnoalliance.com/wordpress/?p=2309

World Social Forum. (2005). World charter on the right to the city. Retrieved from http://www. urbanreinventors.net/3/wsf.pdf

Wright, Talmadge (1997). Out of place: Homeless mobilizations, subcities, and contested landscapes. Albany, NY: SUNY Press. 